\title{
THE NORDIC LEGAL FAMILY AND UNIFICATION OF LAWS
}

Ole HASSELBALCH, doctor of law, professor (em.) at the Aarhus University (the Kingdom of Denmark), reader at Stockholm University

Nordre Ringgade 1, 8000 Aarhus C

E-mail: ole.hasselbalch@mail.dk

In the presented article the author analyses the particular and typical legal characteristics of the so-called Nordic Legal Family, which enable it to be rather specific and to be on the contrary to the Romano-Germanic legal family and the Anglo-Saxon legal families of Europe. The author emphasizes that these characteristics of Nordic legal family serve the cause of the harmonisation of the laws and even legal systems of the States of Northern Europe included in this legal family. The author examines the ethnic, historical and cultural origins, the foundations of the origin of this legal family, and based on them factors that contribute to the harmonization of their laws. The specifics of the formation of legal systems of the States of this region were shown in present article. The author describes the traditional North-European countries forms and methods of legal unification through meetings and consultations of their representatives, through their joint activities, their activities in the Northern Council which is an international body of inter-parliamentary cooperation, and the Council of Ministers of Nordic Council member states whish is responsible for intergovernmental cooperation. There also were presented the examples of positive results of this unification. However, the author correlates the operation of the Nordic legal family and the negative influence of the European law.

Keywords: law, legislation, unification, legal family, legal characteristics, background, experience, comparative, lawyers.

\section{СЕВЕРНАЯ ПРАВОВАЯ СЕМЬЯ И УНИФИКАЦИЯ ЗАКОНОВ}

\author{
ХАССЕЛЬБАЛЬК Оле, заслуженный профессор Орхусского университета, лектор Стокгольмского университета, \\ доктор права \\ г. Орхус, Дания \\ E-mail: ole.hasselbalch@mail.ru
}

В представленной статье анализируются характерные правовые особенности так называемой северной правовой семьи, которые отличают ее от романо-германской и англосаксонской правовых семей Европы. Автор подчеркивает, что именно эти свойства северной правовой семьи способствуют плодотворной унификации законодательств и даже правовых систем государств Северной Европы, входящих в указанную правовую семью. Автор статьи рассматривает этнические, исторические и культурные истоки, основы зарождения этой правовой семьи, а также базирующиеся на них фракторы, способствующие унификации законов. Показана специфика фрормирования правовых систем государств этого региона. Автор описывает традиционные для североевропейских государств формы и способы правовой унификации посредством встреч и консультаций их представителей, с помощью проводимых ими совместных мероприятий, а также в процессе их деятельности в Северном совете, который является международным органом межпарламентского сотрудничества, и в Совете министров стран - членов Северного совета, ответственного за их межправительственное взаимодействие. Приводятся примеры положительных результатов этой унификации. Вместе с тем автор соотносит функционирование северной правовой семьи и влияние, которое она испытывает со стороны европейского права, оценивая это явление отрицательно.

Ключевые слова: закон, законодательство, унификация, правовая семья, правовые характеристики, первооснова, опыт, сравнительный, правоведы.

\section{DOI: $10.12737 / 24287$}

will focus not upon conflicts of laws, but on how to avoid such conflicts. And I will use The nordic law family and unification of laws as an example.

\section{The Law Families}

A comparative perspective - meaning the comparison of different legal systems - is an essential tool for a legal scholar, since it contributes to the study of any national legal system by adding new approaches to the study of it and by extending the body of examples dealt with in national case law. If one accepts that legal science does not only mean focusing on a national legal system, but

\footnotetext{
* В основе статьи - доклад автора на VI Международном конгрессе сравнительного правоведения «Современное правосудие: национальное и международное измерения» (Москва, 1 декабря 2016 г.).
}

also developing solutions to social conflicts between members of that society, a comparative study, i.e. the study of foreign legal systems, is essential.

A huge number of national legal systems apply in the numerous countries of the world. However, as far as we are able to talk about legal systems at all in a country, each of them is usually qualified as belonging to a law-family, i. e. a body of central conceptions, which penetrates the individual rules. The existence of such law-families facilitates the comparative study.

I will - in brief - introduce you to one of those families and to the system of internal comparison and cooperation of the countries within that system.

\section{The Nordic Law Family}

The standpoint of the present author is that Nordic (by some called Scandinavian) law - meaning law applied 
in Denmark (including Greenland and the Faroe Islands), Finland (including the Aaland Islands), Iceland, Norway and Sweden - has its own characteristics to such a degree that from a comparative perspective it qualifies as a law family of its own.

Several efforts have been made to identify such families. Thus, some scholars adhere to a distinction between the Romanistic, Germanic, Anglo-Saxon, Slav and Islamic families. Others distinguish between French, German, Scandinavian (Nordic), English Russian, Islamic and Hindu law and yet other ones or between Western systems, socialist systems, Islamic law, Hindu law and Chinse law. It has also been suggested to divide the Westerns systems into the Romanistic-German family (the so-called Civil Law system) and the Common Law family and alongside the systems affected by religion Hindu law, Islamic law, law of the Far East and African and the Malagasy law.

One of the main difficulties in making such distinctions at all is that it is not easy to find suitable criteria. What are we to take into account when we identify a law-family? The sources of formal law and its structural system? The legal style, argumentation and thinking? The effectiveness of the formal rules? Judicial reasoning and the mentality of the actors on the scene? The court system and or the legal training of lawyers? The political ideology or religion? Law's background in economics and philosophy?

Anyway, it is clear, that Nordic law cannot be allocated to Common Law. Thus the history of Nordic Law is quite independent of that of English Law. Nordic law carries none of the stylistic hallmarks of Common Law either (such as the role of the judge, the methods of finding law and the strong emphasis on case-law). Nor does Nordic law fit into the concepts of Civil Law applied in most of Continental Europe with its roots heavily planted in Roman law and its extensive use of statutes and comprehensive codes (law-books). Truly, Nordic law has some codes, but none comparable to codes such as for example the French Code Civil or the German Bürgerliches Gesetzbuch (BGB). Nor has Nordic law a basis in extensive conceptualism and forming of exhaustive theoretical systems - even if legal concepts and formal legislation is in fact used instead of precedents as in common law. So one may say that Nordic Law is in an "in between" position.

This is due not only to the fact that Nordic law has basically developed independently of the other European legal systems, but also to the fact that historically seen this development has happened on the basis of a common Nordic political, economical, social and cultural development. This development forms the basis of rather identical ideas as to how to solve quite a number of central legal problems in those countries. Part of this is the fact that the Nordic countries share a number of basic legal principles. And on the top of it, for more than 100 years there has even been an intensive formal as well as an informal cooperation between the Nordic countries in an effort to harmonize their body of legislation - see below.
So today there is ample reason to identify Nordic law as a law family of its own ${ }^{1}$.

The Basis of the Legal Systems in the Nordic Countries

Historically speaking Nordic law is deeply rooted in old (unwritten) Germanic law with some regional variations, memorized by law-speakers. In the twelfth century and later this body of rules was written down in a number of local laws and city laws. These laws were eventually compiled in more comprehensive law-books such as in Sweden Land Law for the lowlands and a City Law for the towns, later on (1734) Sveriges Rikes Lag - Code of the Swedes; in Denmark / Norway in Danske Lov (Law of the Danes, 1683) and Norske Lov (Law of the Norwegians, 1687). All of them drafted in a simple style and focusing upon (numerous) casuistic details rather than on theoretical generalization. Undue conceptualism and large-scale integrated theoretical systems have never got foothold in Scandinavia, even if there was some influence from Continental Europe - in particular in Sweden in special fields where the old law books were deficient. But this influence never changed the very core of the legal systems.

Another characteristic feature of Nordic law is the particular role of the courts. In Germany for example, judges went ahead of the legislator and developed the rules of BGB according to changing needs of society. And in Common Law countries the judges are not only anonymous voices expressing the content of the law instead they speak as human beings to other human beings whom they try to convince by involving the reader of the ruling in the considerations behind it and by explaining these considerations as extensively as possible. In traditional Nordic law as a contrast, the judge is the neutral transmitter of the law, which he is not entitled to influence himself. Thus, the Nordic courts are not allowed to make a ruling beyond what has been decided by Parliament either by way of passing a formal Act on the issue $o r$ by accepting - meaning not interfering in custom and practice as valid law. So the judge's task is only to decide what should be regarded as the facts of the individual case on the basis of the proofs presented to the court by the parties and to apply already valid law on this fact. So, even if Nordic judges have room to decide the outcome of a lawsuit, their hands are tied by the intentions of the legislator (the Parliament), which can be read in the parliamentary preparatory works, and in custom and practice accepted by the Parliament. If a judge makes new law on his own he is - according to this concept - interfering in the Parliament's job. So a

\footnotetext{
${ }^{1}$ See i.a. Ulf Bernitz, What is Scandinavian Law? Concept, Characteristics, Future, Scandinavian Studies in Law, vol. 39, 2000, p. 29-42; Jaakko Husa, Kimmo Nuotio and Heikki Pihlajamäki (eds.), Nordic Law - Between Tradition and Dynamism (Metro, 2007); Konrad Zweigert and Hein Kötz, An Introduction to Comparative Law, Part I, $3^{\text {rd }}$ ed., 1998, vol. I, B IV.
} 
judge is not allowed to make a 'dynamic' ruling as is, for example, the European Court of Justice - he may only rule on the basis of valid law passed or accepted by the Parliament so it has what has been called "democratic legitimation".

\section{Unification of Nordic Law}

The Scandinavian countries have extensive experience in cooperation in the legal field and in unification of laws.

The very basis of this is the fact that the Nordic countries have not only their legal history in common, they have also had a common historical and cultural development. Furthermore, the Scandinavian languages (except Finnish, but Finland has Swedish as its second language) are closely related to such a degree, that most Scandinavians understand each other without translation (if spoken distinctly). Therefore, it was only natural that the Nordic countries during the last third of the nineteenth century started to co-operate closely on the formal level in the field of legislation in order to facilitate also the increase in trade and the improvement of traffic. Even if this effort was not based upon any kind of supranational authority (as is for example that of the European Union) this has created a body of identical or mostly identical laws.

Thus numerous unified laws in the form of identical or almost identical - Acts have been passed in all the Scandinavian countries: on negotiable instruments, trademarks, commercial registers, firms, cheques, maritime issues, sales of movables, insurance contracts, companies, bankruptcy, contracts in general, law on marriages and inheritance, mercantile agents, copyright, unfair competition, patents, enforcement of judgements etc. ${ }^{2}$ It should be mentioned that all of them have been preceded by comparative research also on the solutions given by other law families in order to find the solutions best fit for the Nordic countries.

This extensive effort in the field of legislation did not only facilitate trade, commerce and travel. I also lead to a better quality of legislation. Thus, due to the relatively small populations of each individual country experience within one country only is limited. But on the basis of the unified laws, it has been possible to draw on each other's body of court rulings - even if the laws of the individual countries are formally independent of each other, court rulings usually run along identical lines legal literature and practical experience. Moreover, it is possible to simplify preparation of new Acts since such preparation might be performed by one body only instead of by a body for each individual country.

Also among academics, the Nordic cooperation has been an enormous advantage and compensates for the

\footnotetext{
${ }^{2}$ See on this i.a. W. E. von Eyben, Inter-Nordic Legislative Co-operation, Scandinavian Studies in Law, vol. 6, 1962, p. 6393 (with further references); Jan Hellner, Unification of Law in Scandinavia, The American Journal of Comparative Law, 16,1968, p. $88 \mathrm{ff}$.
}

smallness of the individual countries. Thus, it is possible to draw on each other's literature and to cover special fields of research which would be beyond the economic limits of one country only to deal with. Also in assessment boards of the universities, it is quite common to involve expertize from other Nordic countries. Even at the teaching level in universities, teachers regularly cross the borders - the present author for example holds a formal post of reader (docent) at the Stockholm law faculty and his own faculty in Aarhus has professor Stein Evju, Oslo University, also as professor with us.

\section{The Nordic Council}

Since 1952 this development has taken place under the auspices of The Nordic Council, which was established that year (Finland joining from 1955). Under its auspices, efforts are made to facilitate cooperation in all fields of life - politically, economically and culturally.

The Nordic Council itself is the forum for the cooperation of parliamentarians from all the Nordic countries. In all there are 87 members from the national Parliaments - Denmark, Finland, Norway and Sweden 20 each, Iceland 7. Two of the Danish representatives come from Greenland and the Faroe Islands, two of the Finnish ones from Aaland. Its task is to point out issues for the relevant ministers to take care of.

The Nordic Council of Ministers is meetings among the respective resort ministers twice a year, where they take decisions which all agree upon - each country having one vote. In other word: the consensus principle applies.

\section{Meetings of Lawyers}

A driving factor in the cooperation in the legal field is also a formalized close cooperation between Nordic lawyers, most markedly channeled through regular Nordic Lawyers Meetings (since 1872). At these meeting, attorneys, judges, public servants etc. meet and discuss common topics on the basis of reports and co-reports made by authors from the different countries. These reports oftentimes assume the character of genuine monographies and the proceedings at the meetings are published afterwards. These meeting are important sources of inspiration for legislative work.

It should be added that Nordic meetings take place also between students and lawyers in different positions (such as those employed by unions and employers' organisations) - each dealing within their field of interest.

Effect of the European Economic Community (EEC) and the European Union (EU)

When Denmark joined the European Economic Community in 1972, development towards Nordic unification of law came to a hold since Denmark from then on had to conform to the EEC- regulations instead. However, since the beginning of the 1990s even Sweden and Finland joined the EEC - and Norway and Iceland had to abide by the same rules due to their attachment to the EEA (the European Economic Area). This meant that all Nordic countries now have to consider the more and more extensive regulation on a common European basis. 
This European legislation was from the start on confined to limited areas of law, but has developed in a way which also affects the underlying values in a way which interferes in the traditional Nordic legal values. Consequently, Nordic law nowadays is being integrated more and more in the general European (EU) legal system.

\section{REFERENCES}

Ulf Bernitz, What is Scandinavian Law? Concept, Characteristics, Future, Scandinavian Studies in Law, vol. 39, 2000.

Jaakko Husa, Kimmo Nuotio and Heikki Pihlajamäki (eds.), Nordic Law — Between Tradition and Dynamism (Metro, 2007).

Konrad Zweigert and Hein Kötz, An Introduction to Comparative Law, Part I, Third Edition 1998, vol. I, B IV.

W. E. von Eyben, Inter-Nordic Legislative Co-operation, Scandinavian Studies in Law, vol. 6, 1962.

Jan Hellner, Unification of Law in Scandinavia, The American Journal of Comparative Law, 16, 1968. 